Short communication

\title{
CHARACTERIZATION OF TETRACYCLINE RESISTANCE OF SALMONELLA ENTERICA SUBSPECIES ENTERICA SEROVAR INFANTIS ISOLATED FROM POULTRY IN THE NORTHERN PART OF SERBIA
}

\author{
TODOROVIĆ Dalibor ${ }^{1}$, VELHNER Maja ${ }^{1 *}$, MILANOV Dubravka ${ }^{1}$, VIDANOVIĆ \\ Dejan², SUVAJDŽIĆ Ljiljana ${ }^{3}$, STOJANOV Igor ${ }^{1}$, KRNJAIĆ Dejan ${ }^{4}$
}

\begin{abstract}
${ }^{1}$ Scientific Veterinary Institute „Novi Sad“, Novi Sad, Republic of Serbia; ${ }^{2}$ Veterinary Institute Kraljevo, Kraljevo, Republic of Serbia; ${ }^{3}$ Faculty of Medicine, Department of Pharmacy, University of Novi Sad, Republic of Serbia; ${ }^{4}$ Faculty of Veterinary Medicine Belgrade, University of Belgrade, Republic of Serbia
\end{abstract}

(Received 16 July; Accepted 13 November 2015)

\begin{abstract}
Resistance to tetracycline was studied in Salmonella Infantis isolated from 28 poultry farms in the Northern part of Serbia (The Autonomous Province of Vojvodina). A total of 18 isolates were resistant to nalidixic acid (NAL) and tetracycline (TET). The minimal inhibitory concentration (MIC) to TET, ranged from 1-256 mg/L. Namely, 13 isolates exhibited MIC to TET at $256 \mathrm{mg} / \mathrm{L}$, in four of the isolates, the MIC was $128 \mathrm{mg} / \mathrm{L}$ and one isolate had MIC $64 \mathrm{mg} / \mathrm{L}$. Ten isolates were exhibiting a MIC of $1 \mathrm{mg} / \mathrm{L}$. It was evident that Salmonella Infantis had also spread to breeders and layers. In this work, we detected the tet $A$ gene and the corresponding tet $\mathrm{R}$ gene (encoding the repressor protein) as well as the truncated transposon $\operatorname{Tn} 1721$, which are responsible for the resistance to TET. The presence of the non conjugative transposons from the conjugative plasmid has facilitated the spread of resistance to TET in Salmonella. It was concluded that higher biosecurity practice in poultry farming presents the best option to eliminate infections caused by Salmonella spp. from poultry flocks in Serbia. A rational use of antimicrobials is necessary to prevent any further spread of Salmonella Infantis resistant clones.
\end{abstract}

Key words: poultry, Salmonella Infantis, tetracycline, tet $A$ gene, tetR gene, transposone $\operatorname{Tn} 1721$

\section{INTRODUCTION}

Salmonella is one of the most important food borne pathogens worldwide. The occurrence of Salmonella Infantis ( $S$. Infantis) in poultry production in Serbia is important. By applying pulse field gel electrophoresis, it was determined that strains resistant to NAL and TET are indistinguishable [1,2]. The clones resistant to (fluoro)

\footnotetext{
*Corresponding author: e-mail: maja@niv.ns.ac.rs
} 
quinolones and TET were recently found in all types of commercial chickens i.e. broiler breeders, layer breeders, broilers and layer chickens [3]. Ultimately, the incidence of $S$. Infantis has to be minimized in poultry farms in Serbia. The mechanism of resistance to (fluoro) quinolones is attributed to the mutations on the topoisomerase genes encoding GyraseA and the topoisomerase IV enzymes. A single mutation on the gyr A gene Ser83 $\rightarrow$ Tyr was found in the nalidixic acid resistant strains, while in isolates with an increased MIC to ciprofloxacin (CIP) of $2 \mathrm{mg} / \mathrm{L}$, additional mutations were found on parC gene at Ser80 $\rightarrow$ Arg [2].

The genes responsible for the resistance to TET were not elucidated. Tetracycline inhibits protein synthesis by preventing the association of the aminoacyl tRNA to the A site of the ribosome. Hence, the resistance is encoded by the family of tet genes. According to amino acid sequence identity, the tet genes encoding the membrane bound proteins, are divided in 6 groups. The first group consisted of the following genes: $\operatorname{tet}(\mathrm{A}), \operatorname{tet}(\mathrm{B}), \operatorname{tet}(\mathrm{C}), \operatorname{tet}(\mathrm{D}), \operatorname{tet}(\mathrm{E}), \operatorname{tet}(\mathrm{G}), \operatorname{tet}(\mathrm{H}), \operatorname{tet}(\mathrm{I}), \operatorname{tet}(\mathrm{J}), \operatorname{tet}(\mathrm{Z})($ the $\operatorname{tet} \mathrm{Z}$ gene is also found in Gram positive bacteria), tet(30) and tet(31). The second group consisted of the $\operatorname{tet}(\mathrm{K})$ and $\operatorname{tet}(\mathrm{L})$ genes. In the third group, the $\operatorname{tr}(\mathrm{B})$ and $\operatorname{tcr} 3$ genes were classified. In groups IV and V the tet $(\mathrm{P})$ and tet $(\mathrm{V})$ genes were found, respectively. Group VI was represented by an unnamed determinant from Corynebacterium striatum. Ribosomal protection proteins confer the resistance to doxycycline and minocycline. The genes encoding this type of resistance are so far $\operatorname{defined}$ as: $\operatorname{tet}(\mathrm{M}), \operatorname{tet}(\mathrm{O}), \operatorname{tet}(\mathrm{S})$, $\operatorname{tet}(\mathrm{W}), \operatorname{tet}(\mathrm{Q}) \operatorname{tet}(\mathrm{T}), \operatorname{otr}(\mathrm{A}), \operatorname{tet} \mathrm{B}(\mathrm{P})$ and some genes without the $(\operatorname{tet})$ designation have also been identified. A less abundant mechanism of resistance is the enzymatic inactivation of tetracycline, encoded by the tet $X$ gene. The tet genes are associated with mobile genetic elements - the transposons, which are integrated into conjugative or non conjugative plasmids of different incompatibility groups [4]. In Salmonella, the tet genes are detected on chromosomes or less frequently on plasmids. The tet $A$ gene is found in the truncated non-conjugative transposons Tn1721 inserted into the conjugative plasmid [5-7].

The aim of this study was to isolate $S$. Infantis from poultry farms in the Autonomous Province of Vojvodina during the year 2014 and to determine the antimicrobial susceptibility profiles, as well as TET resistance genes in the antibiotic-resistant isolates.

\section{MATERIAL AND METHODS}

\section{Bacterial isolates, isolation, identification and storage}

During the year 2014, regular monitoring of the Salmonella status was carried out in 55 poultry farms located in the Autonomous Province of Vojvodina. Salmonella Enteritidis was isolated from 26 farms and in one farm Salmonella Typhimuirum was detected. S. Infantis was isolated from 28 poultry farms, comprising of 22 broiler farms, one broiler breeder farm and five farms of layer chickens. 
The detection of Salmonella spp. in animal feces and in environmental samples from the primary production stage was done as prescribed in the EN ISO 6579:2008, Annex D [8] by applying: pre enrichment in buffered peptone water (BPW), selective enrichment on modified semi-solid Rappaport-Vassiliadis agar; isolation on a selective medium Xylose Lysine Deoxycholate (XLD) agar. All the media were from Biokar diagnostics (Bequvais, CEDEX-FRANCE). Salmonella differential agar (HIMEDIA, Mumbai, India) was also used for selection of Salmonella colonies.

The identity of isolates was confirmed by biochemical testing which included: triple sugar agar, urea agar (Christensen), Lysine decarboxylase broth, the detection of $\beta$-galactosidase (ONPG disc), and the Voges-Proskauer (VP) test [8]. The serotyping was done with sera against somatic $(\mathrm{O}: 6,7)$ and flagellar (H phase 1:r and phase 2:1,5) antigens [9]. Up until testing, the strains were stored in Tryptone soya broth (TSB) (CM0129, Oxoid, Basingstoke, UK) with $15 \%$ glycerol at $-20^{\circ} \mathrm{C}$. Overnight cultures, cultivated on XLD agar at $37^{\circ} \mathrm{C}$, were used for the examination.

\section{Antimicrobial susceptibility testing and the determination of minimal inhibitory concentration (MIC)}

Antimicrobial susceptibility test methods were performed according to The Clinical Laboratory Standard Institute documents [10,11]. A reference strain, Escherichia coli ATCC 25922, was used for quality control purposes. S. Infantis isolates were investigated for antibiotic susceptibility by applying the disc diffusion method on Mueller-Hinton agar (CM0337, Oxoid, Basingstoke, UK) while using the following antibiotic disc: Ampicilin $10 \mu \mathrm{g}$ (AMP), Amoksicilin/clavulanic acid $20 \mu \mathrm{g}+10 \mu \mathrm{g}$ (AMC), Chloramphenicol $30 \mu \mathrm{g}$ (CAP), Ciprofloxacin $5 \mu \mathrm{g}$ (CIP), Gentamycin $10 \mu \mathrm{g}$ (GEN), Nalidixic acid $30 \mu \mathrm{g}$ (NAL), Streptomycin $10 \mu \mathrm{g}$ (STR), Sulphonamides 300 $\mu \mathrm{g}$ (SA), Tetracycline $30 \mu \mathrm{g}$ (TET), Trimethoprim/sulfamethoxazole $1.25 \mu \mathrm{g}+23.75$ $\mu \mathrm{g}$ (SXT), Trimethoprim $5 \mu \mathrm{g}$ (TMP), Cefpodoxime $10 \mu \mathrm{g}$ (CPD), Cefotaxime $30 \mu \mathrm{g}$ (CTX), Ceftazidime $30 \mu \mathrm{g}$ (CAZ), (BioRad, Marnes-la-Coquette, France). Resistance to tetracycline was interpreted at MIC $\geq 16 \mathrm{mg} / \mathrm{L}$. The tetracycline powder was from Sigma Aldrich (München, Germany).

\section{Polymerase chain reaction protocols}

The polymerase chain reaction (PCR) was conducted to detect, tet $A, \operatorname{tet} B, \operatorname{tet} C, \operatorname{tet} D$, tetE, tet $G$ genes, the transposon $\operatorname{Tn} 1721$, the left and the right arm of the $\operatorname{Tn} 1721$ and also the repressor gene tet $(\mathrm{R})$. DNA was isolated using the boiling procedure $\left(100^{\circ} \mathrm{C}\right.$ for 5 minutes) and the master mix was prepared from the HotStarTaq master Mix kit according to the manufacturer instruction (Qiagen, Hilden, Germany). The PCR was performed by using the Thermal cycler TECHNE (Bibby Scientific LTD, UK) under the following conditions for the tet genes: denaturation at $95^{\circ} \mathrm{C} 15 \mathrm{~min}, 30$ cycles at $94^{\circ} \mathrm{C} 1 \mathrm{~min}, 55^{\circ} \mathrm{C} 1 \mathrm{~min}, 72^{\circ} \mathrm{C} 1 \mathrm{~min}$, extension at $72^{\circ} \mathrm{C} 10 \mathrm{~min}$. The cycling conditions for the detection of the $\operatorname{Tn} 1721$ and the left arm of the transposon were: $95^{\circ} \mathrm{C}, 15$ 
min, 30 cycles at $94^{\circ} \mathrm{C}, 30 \mathrm{~s}, 53^{\circ} \mathrm{C}, 1 \mathrm{~min}, 72^{\circ} \mathrm{C} 1 \mathrm{~min}$, and the final step at $72^{\circ} \mathrm{C}$, for 7 min. For the detection of the right arm of the $\operatorname{Tn} 1721$ and the tetR gene the cycling conditions were, $15 \mathrm{~min}$ at $95^{\circ} \mathrm{C}, 30$ cycles at $94^{\circ} \mathrm{C}$ for $30 \mathrm{sec}$, annealing at $55^{\circ} \mathrm{C}$ for 1 $\mathrm{min}$, and $72^{\circ} \mathrm{C}, 1 \mathrm{~min}$, the final extension was $72^{\circ} \mathrm{C}$ for $7 \mathrm{~min}$. The sequences of the primers, the amplicon size and the references used in this work are presented in Table 1. PCR products were analyzed on a 2\% gel (AppliChem, Darmstadt, Germany).

Table 1. The sequence of primers (5'-3'), annealing temperature, fragment size and references used in the study

\begin{tabular}{|c|c|c|c|c|}
\hline $\begin{array}{l}\text { Primer } \\
\text { name }\end{array}$ & Primer sequence & $\begin{array}{l}\text { Anneal. } \\
\text { temp. } \\
{ }^{\circ} \mathrm{C}\end{array}$ & $\begin{array}{c}\text { Fragment } \\
\text { size } \\
\text { bp }\end{array}$ & Reference \\
\hline tet $\mathrm{AF}$ & GCT ACA TCC TGC TTG CCT TC & 55 & 210 & 12 \\
\hline tetAR & CAT AGA TCG CCG TGA AGA GG & & & \\
\hline tetBF & TTG GTT AGG GGC AAG TTT TG & 55 & 659 & 12 \\
\hline tetBR & GTA ATG GGC CAA TAA CAC CG & & & \\
\hline tetCF & CTT GAG AGC CTT CAA CCC AG & 55 & 888 & 12 \\
\hline tetCR & ATG GTC GTC ATC TAC CTG CC & & & \\
\hline tetDF & AAA CCA TTA CGG CAT TCT GC & 55 & variable & 12 \\
\hline tetDR & GAC CGG ATA CAC CAT CCA TC & & & \\
\hline tetEF & АAА ССА САТ ССТ ССА ТАC GC & 55 & variable & 12 \\
\hline tetER & AAA TAG GCC ACA ACC GTC AG & & & \\
\hline tetGF & CAG CTT TCG GAT TCT TAC GG & 55 & variable & 12 \\
\hline tetGR & GAT TGG TGA GGC TCG TTA GC & & & \\
\hline TAF & GTA ATT CTG AGC ACT GTC GC & 53 & 1199 & 6 \\
\hline tetAR3 & GGC ATA GGC CTA TCG TTT CCA & & & \\
\hline LAF & GTT CGG GTC AGC AGC TTT GAC & 53 & 509 & 6 \\
\hline LAR & GAG GGT TTC CCG GCT GAT GT & & & \\
\hline TRF & CGT ATG ATT CTC CGC CAG CA & 55 & 736 & 7 \\
\hline TAR2 & CGA CCA TCC CGA ACC CGA A & & & \\
\hline TAF2 & CTT CTT CAT CAT GCA ACT TGT & 55 & 912 & 7 \\
\hline $\operatorname{Tn} 1721 \mathrm{R}$ & CGT TCC AGT AGC TTTT AGT GT & & & \\
\hline
\end{tabular}

\section{RESULTS AND DISCUSSION}

Resistance to TET in strains of $S$. Infantis from Serbia is the prominent property of the clones. The reason why this research was conducted was to determine the genes responsible for resistance to TET. 
S. Infantis was isolated from 28 poultry farms out of 55 in the Northern part of Serbia. Three resistotypes were detected but the most prevalent resistance was to NAL and TET in 18 of the isolates. Two isolates were resistant only to NAL and eight isolates were susceptible to antibiotics. The MIC distribution is presented in Table 2. Most of the strains exhibited high MIC to TET, ranging from $64-256 \mathrm{mg} / \mathrm{L}$. In 10 out of 28 isolates the MIC to TET was $1 \mathrm{mg} / \mathrm{L}$.

Table 2.

\begin{tabular}{|c|c|c|c|c|c|c|c|c|c|}
\hline $\begin{array}{c}\text { No } \\
\text { of the } \\
\text { sample }\end{array}$ & $\begin{array}{l}\text { Poultry } \\
\text { flock }\end{array}$ & Resistotype & $\begin{array}{c}\text { MIC-CIP } \\
\mathrm{mg} / \mathrm{L}\end{array}$ & $\begin{array}{c}\text { MIC-TET } \\
\mathrm{mg} / \mathrm{L}\end{array}$ & tetA* & Tn1721 & $\begin{array}{c}\text { Left Arm } \\
\text { Tn1721 }\end{array}$ & tet(R) & $\begin{array}{c}\text { Right } \\
\text { Arm } \\
\text { Tn1721R }\end{array}$ \\
\hline 3947 & Broilers & 1 & 0,031 & 1 & - & - & - & - & $\mathrm{ND}^{* *}$ \\
\hline 4143 & Broilers & NAL & 0,5 & 1 & - & - & - & - & ND \\
\hline 4682 & Broilers & NAL, TET & 2 & 256 & + & + & - & + & + \\
\hline $4716 / 1$ & Broilers & NAL, TET & 2 & 256 & + & + & - & + & + \\
\hline 4855 & Broilers & NAL, TET & 2 & 256 & + & + & - & + & + \\
\hline 5580 & Broilers & NAL, TET & 4 & 256 & + & + & - & + & + \\
\hline 5582 & Broilers & NAL, TET & 2 & 256 & + & + & - & + & + \\
\hline 5656 & Broilers & NAL, TET & 0,25 & 128 & + & + & - & + & + \\
\hline $5736 / 1$ & Broilers & NAL, TET & 1 & 256 & + & + & - & + & + \\
\hline $7639 / 3$ & Broilers & NAL, TET & 1 & 256 & + & + & - & + & + \\
\hline 9643 & Broilers & NAL, TET & 1 & 256 & + & + & - & + & + \\
\hline 9784 & Broilers & / & 0,031 & 1 & - & - & - & + & + \\
\hline $9849 / 2$ & Broilers & I & 0,007 & 1 & - & - & - & - & ND \\
\hline 10175 & Broilers & / & 0,015 & 1 & - & - & - & - & ND \\
\hline 10101 & Broilers & NAL, TET & 2 & 256 & + & + & - & + & + \\
\hline 9699 & Broilers & NAL, TET & 0,25 & 64 & + & + & - & + & + \\
\hline $11420 / 2$ & Broilers & NAL, TET & 1 & 256 & + & + & - & + & + \\
\hline 11288 & Broilers & NAL, TET & 2 & 256 & + & + & - & + & + \\
\hline 10596 & Broilers & NAL, TET & 2 & 256 & + & + & - & + & + \\
\hline 12913 & Broilers & NAL/TET & 1 & 128 & + & + & - & + & + \\
\hline 12140 & Broilers & NAL, TET & 2 & 256 & + & + & - & + & + \\
\hline $13220 / 1$ & Broilers & NAL, TET & 0,5 & 128 & + & + & - & + & + \\
\hline 5653 & Layers & NAL, TET & 0,25 & 128 & + & + & - & + & + \\
\hline 6597 & Layers & / & 0,031 & 1 & - & - & - & - & ND \\
\hline $9815 / 2$ & Layers & NAL & 0,5 & 1 & - & - & - & - & ND \\
\hline 12777 & Layers & / & 0,015 & 1 & - & - & - & - & ND \\
\hline 12473 & Layers & I & 0,007 & 1 & - & - & - & - & ND \\
\hline 8761 & $\begin{array}{l}\text { Broiler } \\
\text { Breeder }\end{array}$ & I & 0,015 & 1 & - & - & - & - & ND \\
\hline
\end{tabular}

*tet $A$ gene, Tn1721 (transposon), Left arm Tn1721 (left arm of the transposon), tet(R), the repressor gene; Right Arm Tn1721 (right arm of the Tn1721 transposon); ** Not done 
The genes which encode resistance to TET are found on mobile genetic elements, the transposons. In this work we detected the tet $A$ gene and the truncated non conjugative transposon Tn1721 in $S$. Infantis, isolated from poultry flocks in the Autonomous Province of Vojvodina. None of the $S$. Infantis isolates contained the tet $B$, tet $C$, tet $D$, tet $E$ and $t e t G$ genes. We have also identified the tet $R$ gene which is responsible for encoding the repressor protein and we have detected the right arm of the truncated transposon. In isolates that are not exhibiting resistance to tetracycline, the tet $A$ gene, the $\operatorname{Tn} 1721$ and the tetR genes were not found (Fig 1). The results of our experiments are in good correlation with the evidence that the tet genes are arranged in different conjugative and non conjugative transposons [4]. The functional tet $A$ gene in the truncated transposon Tn1721 was detected for the first time in Salmonella Typhimurium var. Copenhagen DT002. It was elucidated that the Tn1721 is located in the $9.5 \mathrm{kbp}$ plasmid designated pGFT4. Additionally, the Escherichia coli transformant JM107:pGFT4 was highly resistant to TET [5]. In $S$. Typhimurium, isolated from the irrigation water in Culiacan Valley Mexico, the tet $A$ gene and truncated Tn1721 transposon were identified. The tet $A$ gene in $S$. Typhimurium has high sequence homology to the tet gene of the plasmid RP1 [7]. In each case, the non conjugative transposons ( $\operatorname{Tn} 1721)$ were located on the conjugative plasmid, facilitating a wide distribution of the tet genes in nature.

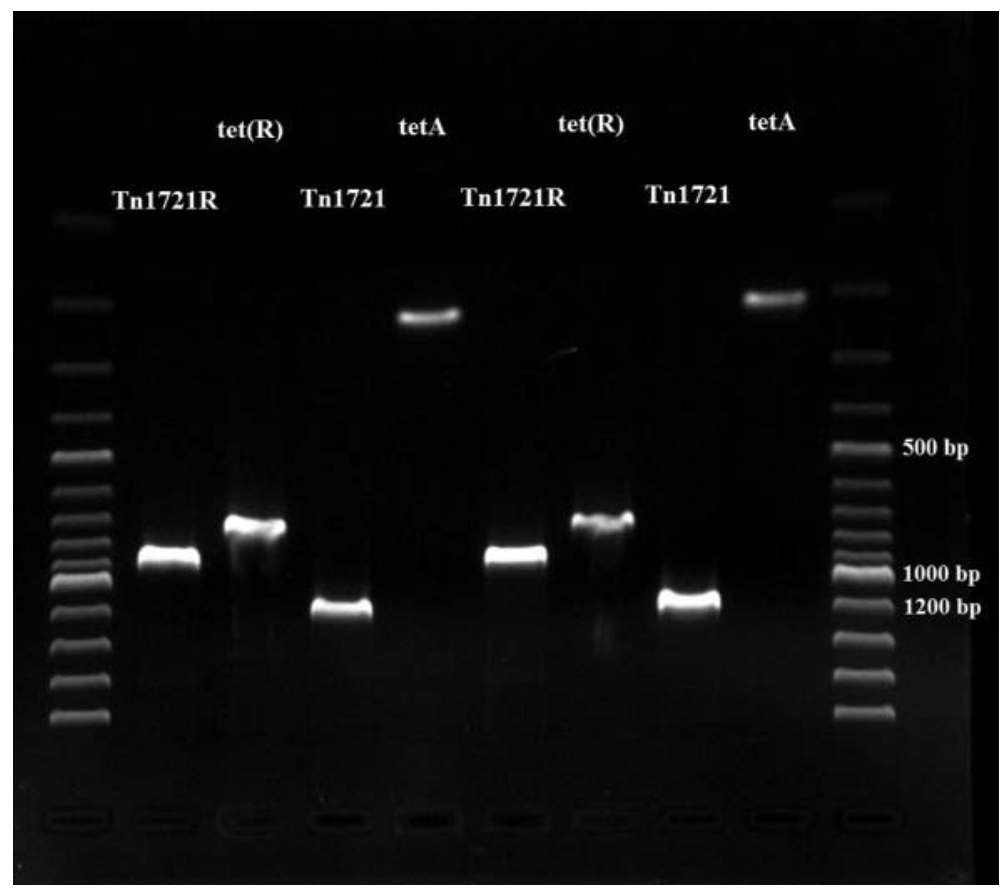

Figure 1. Detection of tet $A$ gene, the repressor gene tet $\mathrm{R}$ and truncated transposon $\operatorname{Tn} 1721$ from $S$. Infantis resistant to NAL and TET 
To this day, several types of tet genes were reported in $S$. Infanits. In Japan and Israel the tet $A$ gene was found in isolates from poultry $[13,14]$. In the epidemiologically unrelated $S$. Infantis, distributed evenly in two clusters obtained by pulsed field gel electrophoresis, the tet $A$ and $t e t B$ genes were found in Italy [15]. The tet $D$ gene was identified in hospital isolates from Rio de Janeiro, Brazil, [16]. Therefore, tet genes of different hybridization classes were found in Salmonella [17].

It is evident that $S$. Infantis is widespread among poultry flocks and also causes gastrointestinal infections in humans. These facts emphasize the need for strict control of Salmonella infections in the poultry industry especially because $S$. Infantis typically found in broilers is also infecting layer chickens. It is plausible that different types of chickens (possibly broilers and layers) are hatched in the same hatchery cabinet and such management practice increases the possibility of clonal spread of $S$. Infantis.

In conclusion, three resistotypes of $S$. Infantis were detected in poultry flocks. Eighteen isolates were resistant to NAL and TET, two isolates were resistant only to NAL and eight isolates were susceptible to all antibiotics used in the study. We have determined that the tet $A$ gene is responsible for the resistance to tetracycline in poultry isolates from $S$. Infantis in the Vojvodina Province. It is plausible that the truncated tranposon Tn1721 is detected in resistant clones of $S$. Infantis. The occurrence of TET resistant clones is attributed to transferable plasmids in Salmonella. Adequate farm management practice is necessary to minimize the occurrence of Salmonella spp. in poultry farms in Serbia.

\section{Acknowledgment}

This work was financially supported by a grant from the Ministry of Education, Science and Technological Development, Republic of Serbia, Project number TR 31071.

\section{REFERENCES}

1. Rašeta M, Teodorović V, Bunčić O, Katić V, Branković-Lazić I, Polaček V, Vidanović D: Antibiotic resistance and molecular studies on Salmonella enterica subspecies enterica serovar Infantis isolated in human cases and broiler carcasses. Acta Vet 2014, 64: 257-268.

2. Velhner M, Kozoderović G, Grego E, Galić N, Stojanov I, Jelesić Z, and Kehrenberg C.: Clonal spread of Salmonella enterica serovar Infantis in Serbia: acquisition of mutations in the topoisomerase genes gyrA and parC leads to increased resistance to fluoroquinolones. Zoonoses Public Hlth 2014, 61:364-370.

3. Todorović D, Velhner M, Pajić M, Milanov D, Polaček V, Bugarski D: Random amplified polymorphic DNA analysis-RAPD and resistance to antimicrobial agents in Salmonella spp. isolated from poultry in Southern Bačka and Srem region. First International Symposium of Veterinary Medicine-ISVM, Vrdnik, Serbia, May 21-23, Proceedings p479-484, Scientific Veterinary Institute "Novi Sad", Novi Sad and Research Veterinary Institute Belgrade, Belgrade 2015. 
4. Chopra I, Roberts M: Tetracycline antibiotics: Mode of action, applications, molecular biology, and epidemiology of bacterial resistance. Microbiol Mol Biol R 2001, 65:232-260.

5. Frech G, Schwarz S: Plasmid-encoded tetracycline resistance in Salmonella enterica subsp. enterica seovars choleraesuis and typhimurium: identification of complete and truncated $\operatorname{Tn} 1721$ elements. FEMS Microbiol Lett 1999, 176:97-103.

6. Pezzella C, Ricci A, DiGiannatale E, Luzzi I, Carattoli A: Tetracycline and streptomycin resistance genes, transposons and plasmids in Salmonella enterica isolates from animals in Italy. Antimicrob Agents Ch 2004, 48:903-908.

7. Lugo-Melchor Y, Quiñones B, Amézquita-López BA, León-Félix J, Garcia-Estrada R, Chaidez C: Characterization of tetracycline resistance in Salmonella enterica strains recovered from irrigation water in the Culiacan valley, Mexico. Microb Drug Resist 2010, 16:185-190.

8. EN ISO 6579:2008: Microbiology of food and animal feeding stuffs - Horizontal method for the detection of Salmonella spp., 2008, International Organization for Standardization, Geneva.

9. Grimont P.A.D. and Weill F.Y. (2007) Antigenic formulae of the Salmonella serovars, $9^{\text {th }}$ edition, WHO Colaborating Center for Reference and Research on Salmonella, Institut Pasteur, France. http://www.pasteur.fr/sante/clre/cadrecnr/salmoms-index.html

10. Clinical and Laboratory Standards Institute 2015: Methods for Dilution Antimicrobial Susceptibility Tests for Bacteria that Grow Aerobically; Approved Standard-Tenth Edition. CLSI document M07-A10. CLSI Wayne, PA, USA.

11. Clinical and Laboratory Standards Institute, 2015: Performance Standards for Antimicrobial Susceptibility Testing; Twenty-Fifth Informational Supplement. Clinical and Laboratory Standards Institute document M100-S25, CLSI, Wayne, PA, USA.

12. Ng LK, Martin I, Alfa M, Mulvey M: Multiplex PCR for the detection of tetracycline resistant genes. Mol Cell Prob 2001, 15:209-215.

13. Shahada F, Chuma T, Tobata T, Okamoto K, Sueyoshi M, Takase K: Molecular epidemiology of antimicrobial resistance among Salmonella enterica serovar Infantis from poultry in Kagoshima, Japan. Int J Antimicrob Ag 2006, 28:302-307.

14. Gal-Mor O, Valinsky L, Weinberger M, Guy S, Jaffe J, Schorr YI, Raisfeld A, Agmon V, Nissan I: Multidrug-resistant Salmonella enterica serovar Infantis, Israel. Emerg Infect Dis 2010, 16:1745-1757.

15. Dionisi AM, Lucarelli C, Benedetti I, Owczarek S, Luzzi I: Molecular characterization of multidrug-resistant Salmonella enterica serotype Infantis from humans, animals and the environment in Italy. Int J of Antimicrob Ag 2011, 38:384-389.

16. Fonseca EL, Mykytczuk OL, Asensi MD, Reis EM, Ferraz LR, Paula FL, Ng LK, Rodrigues DP: Clonality and antimicrobial resistance gene profiles of multidrug-resistant Salmonella enterica seovar Infantis isolates from four public hospitals in Rio de Janeiro, Brazil. J Clin Microbiol 2006, 44:2767-2772.

17. Frech G, Schwarz S: Molecular analysis of tetracycline resistance in Salmonella enterica subsp. enterica serovars Typhimuirum, Enteritidis, Dublin, Choleraesuis, Hadar and Saintpaul: construction and application of specific gene probes. J Appl Microbiol 2000, 89:633-641. 


\section{KARAKTERIZACIJA REZISTENCIJE NA TETRACIKLINE KOD SALMONELLA ENTERICA SUBSPECIES ENTERICA SEROVAR INFANTIS IZOLOVANE OD ŽIVINE U SEVERNOM DELU SRBIJE}

TODOROVIĆ Dalibor, VELHNER Maja, MILANOV Dubravka, VIDANOVIĆ Dejan, SUVAJDŽIĆ Ljiljana, STOJANOV Igor, KRNJAIĆ Dejan

Ispitivana je rezistencija na tetraciklin kod Salmonella Infantis izolovanih sa 28 farmi živine u severnom delu Srbije (Autonomna pokrajina Vojvodina). Ukupno 18 izolata je bilo rezistentno na nalidiksinsku kiselinu (NAL) i tetraciklin (TET). Minimalna inhibitorna koncentracija (MIC) na TET iznosila je od 1-256 mg/L. Trinaest izolata pokazalo je MIC na TET od $256 \mathrm{mg} / \mathrm{L}$, kod četiri izolata utvrđen je MIC od $128 \mathrm{mg} / \mathrm{L}$, a jedan izolat je imao MIC na TET $64 \mathrm{mg} / \mathrm{L}$. Deset izolata je pokazalo MIC od $1 \mathrm{mg} / \mathrm{L}$. Evidentno je da se Salmonella Infantis sa brojlerskih pilića prenela i na nosilje. Detektovan je tet $A$ gen i pripadajući tetR gen (koji kodira represorski protein) kao i skraćeni transpozon Tn1721, koji su odgovorni za rezistenciju na tetraciklin. Pojava nekonjugabilnog transpozona na konjugabilnom plazmidu doprinosi širenju rezistencije na tetraciklin kod salmonela. Zaključeno je da se primenom boljih biosigurnosnih mera mogu eliminisati infekcije izazvane salmonelama na farmama živine u Srbiji. Kako bi se sprečilo dalje širenje rezistentnog klona Salmonella Infantis potrebno je da upotreba antibiotika bude racionalnija. 